supposed that this hydrogen compound may play an important part in the subsequent production of electromotive force. It therefore appeared desirable to obtain experimental evidence as to whether hydrogen is so absorbed. The process we adopted for this purpose was founded upon the observation of Graham that hydrogen associated with palladium reduced ferri- to ferro-cyanide of potassium, and that generally in the occluded condition the element was more active chemically. We had previously ascertained that hydrogen associated with other elements, as platinum, copper, and carbon, was capable of reducing potassium chlorate to chloride. This method seemed to give trustworthy results, and therefore we applied it in this instance. As the result of several trials, however, we found that the amount of hydrogen associated with the reduced lead was almost inappreciable. Small as this quantity is, however, it is by no means impossible that it may be the cause of the exceedingly high electromotive force observed for the first few moments, on joining up a completely formed cell immediately after its removal from the circuit of the charging current. This, however, may be due, as Planté imagined, to the gaseous hydrogen itself. The principal if not the only function of the hydrogen of the water or sulphuric acid is therefore that of reducing the lead compounds.

By a totally different process Prof. Frankland has very recently come to the șame conclusion as ourselves in regard to the exceedingly small amount of occluded hydrogen.

3. Evolution of Oxygen from the Peroxide Plate.Planté noticed a small escape of gas from the negative plate of his cell immediately after its removal from the influence of the charging current. This he attributed to a decomposition of water by means of local circuits between the peroxide and the subjacent lead plate in contact with it.

The explanation we gave in our first paper (NATURE, vol. xxv. p 22I) of the local action which goes on at the negative plate does not account for the escape of any gas - either oxygen or hydrogen. We therefore thought it of interest to ascertain the nature, and if possible the origin, of the gas noticed by Planté.

We found that the escape of gas from a Planté negative plate was very slight, and soon ceased; but we observed that it became much more pronounced when the temperature of the electrolytic liquid was raised. In order to get a sufficient quantity of the gas for examination, we prepared a negative plate according to the procedure of Faure, and then beated it in dilute acid, with an arrangement for collecting the gas as it was evolved. The amount of gas was still very small in comparison with that of the peroxide, but a sufficient quantity was collected to enable us to ascertain that it was oxygen. We next heated some of the electrolytic peroxide apart from the lead plate, and again noticed a similar evolution of gas, which was also found to be oxygen. This shows, therefore, that it was not a result of local action.

The gas has generally some odour of ozone, and, on testing the dilute acid between the plates of a Planté cell, we always found traces of something that bleached permanganate of potassium, and which might be either ozone or peroxide of hydrogen.

The origin of the gas noticed by Planté may be easily attributed to the oxygen which always passes off in quantity from the peroxide plate during the process of "formation." It is only necessary to suppose that some of this becomes condensed on the peroxide, and is gradually eliminated from it when the surrounding conditions are changed. But the matter is capable of another explanation. If peroxide of hydrogen be really formed in the liquid, it will exert its well-known influence on higher oxides, namely, that of reducing them and itself at the same time. As a matter of fact, if peroxide of lead is dropped into peroxide of hydrogen oxygen is evolved.
4. Temperature and Local Action.--Planté has recently pointed out that an elevation of temperature facilitates the formation of his secondary cell (Comptes Rendus, August, I882). The character of the chemical changes which took place at the negative plate led us to think it exceedingly probable that this increase in the rate of formation arose from an augmentation in the amount of local action. Experiment showed such to be the case, Paìrs of similar negative plates on Planté's model were allowed to remain in repose at $\mathrm{II}^{\circ} \mathrm{C}$. and $50^{\circ} \mathrm{C}$. respectively, and the formation of the white sulphate was visibly more rapid at the higher than at the lower temperature. The same is also true with negative plates prepared by Faure's process. Thus we found that two similar plates kept in repose for an hour, the one at $\mathrm{II}^{\circ} \mathrm{C}$. and the other at $50^{\circ} \mathrm{C}$., formed by local action 2.6 and 7.4 per cent. of lead sulphate respectively. On two other plates the proportions were $7^{.6}$ and 9.5 per cent. respectively. These observations of course by no means exclude the idea that an increase of temperature may facilitate the other chemical changes that take place in the formation of a lead and lead-oxide cell.

J. H. GLADSTONE

ALFRED TRIBE

\section{THE LION AT REST}

THE illustration which we give on next page, from $L a$ Nature, is after a photograph of one of the lions in the Zoological Gardens, London. This photograph may be regarded as one of the numerous triumphs of instantaneous photography, valuable both to art and science. The original was rephotographed in Paris directly on wood, by means of a special collodion, at present much used. This has assured a perfectly faithful reproduction of the original, exhibiting all the characteristic details of the lion at rest. The illustration tells its own story.

\section{ON THE RELATIONS OF THE FIG AND THE} CAPRIFIG ${ }^{1}$

THE relations of the fig and the caprifig, or the cultivated varieties of fig and the wild form of the Mediterranean region, have been variously explained by different writers, including those recent ones whose works are cited below. Intimately connected with this question is the process of caprification, so often and so circumstantially described by ancient and modern authors, amongst the later of whom we may mention Gasparrini. Graf Solms-Laubach's essay is an elaborate work of upwards of one hundred quarto pages, embodying the results of much research. Not the least interesting part is that treating of caprification, or perhaps we might say the manner in which fertilisation is effected. The author regards the cultivated edible varieties of fig as constituting one race, and the wild caprifig as another race of one and the same species; and the former as having developed from the latter under the influences of cultivation. Gasparrini, on the contrary, described them as distinct genera. Dr. Fritz Müller takes an altogether different view. He says it appears to bim far more likely that the fig and caprifig represent, as Linnæus supposed, different forms, the male and the female, belonging together, and not proceeding the one from the other, but which developed side by side, before any cultivation, through natural selection. An examination of the facts adduced by Solms-Laubach himself seems to point to the correctness of Müller's view. But we will set them forth as briefly as possible, leaving the reader to judge for himself. The responsibility of their accuracy rests with the author whom we are quoting. It

I "Die Herkunft, Domesticaticn und Verbreitung des gewöhnlichen Feigenbaums (Ficus Carica, L.)." Von Grafen zu Solms-I aubach. (Gëttingen, r882.) - "Caprificus und Feigentaum." Von Fritz Müller. Kosmos tingen, 1882.)- "Caprificus und Fe gentaum." Von Fritz Müller. Kosm6s, della Società Toscana di Scienze Naturali, November, 1882. 